\title{
Urine alkalization facilitates uric acid excretion
}

\author{
Aya Kanbara', Masayuki Hakoda², Issei Seyama ${ }^{1 *}$
}

\begin{abstract}
Background: Increase in the incidence of hyperuricemia associated with gout as well as hypertension, renal diseases and cardiovascular diseases has been a public health concern. We examined the possibility of facilitated excretion of uric acid by change in urine $\mathrm{pH}$ by managing food materials.

Methods: Within the framework of the Japanese government's health promotion program, we made recipes which consist of protein-rich and less vegetable-fruit food materials for $\mathrm{H}^{+}$-load (acid diet) and others composed of less protein but vegetable-fruit rich food materials (alkali diet). Healthy female students were enrolled in this consecutive 5-day study for each test. From whole-day collected urine, total volume, pH, organic acid, creatinine, uric acid and all cations $\left(\mathrm{Na}^{+}, \mathrm{K}^{+}, \mathrm{Ca}^{2+}, \mathrm{Mg}^{2+}, \mathrm{NH}_{4}^{+}\right)$and anions $\left(\mathrm{Cl}^{-}, \mathrm{SO}_{4}{ }^{2-}, \mathrm{PO}_{4}{ }^{-}\right)$necessary for the estimation of acidbase balance were measured.

Results: Urine $\mathrm{pH}$ reached a steady state 3 days after switching from ordinary daily diets to specified regimens. The amount of acid generated $\left(\left[\mathrm{SO}_{4}{ }^{2}\right]\right.$ +organic acid-gut alkai) were linearly related with those of the excretion of acid (titratable acidity $+\left[\mathrm{NH}_{4}{ }^{+}\right]-\left[\mathrm{HCO}_{3}{ }^{-}\right]$), indicating that $\mathrm{H}^{+}$in urine is generated by the metabolic degradation of food materials. Uric acid and excreted urine $\mathrm{pH}$ retained a linear relationship, where uric acid excretion increased from $302 \mathrm{mg} /$ day at pH 5.9 to $413 \mathrm{mg} /$ day at pH 6.5, despite the fact that the alkali diet contained a smaller purine load than the acid diet.
\end{abstract}

Conclusion: We conclude that alkalization of urine by eating nutritionally well-designed food is effective for removing uric acid from the body.

\section{Background}

Hyperuricemia is not only responsible for the generation of gout but also intimately associated with the incidence of cardiovascular diseases, renal diseases, hypertension and diabetes mellitus[1]. To improve hyperuricemia in the case of gout, almost all medical interventions taken at present rely on pharmacological tools, such as uricosuric medicines and xanthine oxidase inhibitors. Because pharmacological approaches are sometimes accompanied by side effects, alternative way to improve uric acid excretion would be helpful.

Hagos, Stein, Ugele, Burckhardt, and Bahn (2007)[2] have provided the general scheme of the commitment of human organic acid transporter 4 (hOAT4) in urate reabsorption in the proximal tubule. In their proposed mechanism similar to the hypothesis made by Guggino,

\footnotetext{
* Correspondence: seyamai@gaines.hju.ac.jp

'Department of Nutrition and Health Promotion, Faculty for Human Development, Hiroshima Jyogakuin University. 4-13-1 Ushita-higashi Higashiku Hiroshima 732-0063 Japan

Full list of author information is available at the end of the article
}

Martin and Aronson (1983)[3] and Kahn and Weinman (1985)[4], hOAT4 can carry out inwardly directed urate transport in exchange with outwardly directed $\mathrm{OH}^{-}$ movement (urate $/ \mathrm{OH}^{-}$exchanger). The intracellular $\mathrm{pH}$ of the proximal tubule cells and, thereby, the $\mathrm{OH}^{-}$gradient is maintained by the luminal sodium-proton exchanger (NHE3). The energy for $\mathrm{Na}^{+}$influx through NHE3 is provided by the favorable electrochemical gradient for $\mathrm{Na}^{+}$generated by the Na-K pump on the basolateral side. This characteristic of hOHT4 gave us a good hint to test whether one can provide an ideal tool without side effects to cure hyperuricemia. Since urine $\mathrm{pH}$ is determined by acid generation from food metabolism, we were able to generate urine having an intentional $\mathrm{pH}$ by eating designed diets. In this report, we will show that designed diets are effective to remove uric acid from the body, in such a way that alkaline urine is more favorable for removal than acid urine. 


\section{Methods \\ Subjects}

Twenty-six healthy university female students ( 21-22 years old, 45-60 kg in body weight and 157-170 $\mathrm{cm}$ in height), who had no health problem records in the physical check up conducted by the university, participated in this study. The ethics committee at Hiroshima Jogakuin University approved the study protocol. All subjects signed informed consent documents. All participants lodged in the dormitory in the campus while the project was going. The condition of health of all participants was monitored by measuring body weight, the change of which was very limited during the projects (within less than $1 \%$ referred to body weight at the beginning of projects).

\section{Diet}

Values for protein, energy and purine contents were extracted from the available data in the $5^{\text {th }}$ ed nutritional table issued by the Japanese Health, Welfare and Labor Department for all diets ingested by 26 subjects. Resultant calculation on the contents of amino acids in the diet which can generate an acid in the catabolic process, such as arginine, lysine, $1 / 2$ histidine, methionine and cystein, yielded $8039 \mathrm{mg} /$ day in the alkali diet and $19458 \mathrm{mg} /$ day in the acid diet. On the other hand, purine contents for diets were calculated to be $306 \mathrm{mg} /$ day in the alkali diet and $533 \mathrm{mg} /$ day in the acid diet. Each diet period lasted 5 days. During each 5 -day period, the diets made by different recipes but using the same compositions of natural food materials (listed as an appendix) were served. All food materials were purchased from local supermarkets. Subjects had free access to mineral water.

\section{Collection of specimens}

Twenty-four-hour urine specimens were collected in bottles and stored in a refrigerator during collection. Volume, pH, titration acid, organic acid and creatinine were measured in a sample from urine collected the day before measurement. Four ml urine sample of each experimental day for every person was stored in a deep freezer for later ion analysis.

\section{Analytical methods}

According to Lennon, Lemann Jr. and Litzow (1966)[5], the production of endogenous acid is determined by the sum of 1) the oxidation of sulfate in the sulfur-containing amino acids, 2) the endogenous formation of unmetabolized organic acids, and 3) the net gastrointestinal absorption of alkali produced by the oxidation of organic cations and anions. Using the simplified method proposed by Oh (1989)[6], the net gastrointestinal absorption of alkali (gut alkali) was estimated by the following formula on the basis of urinary ion concentration: $\left[\mathrm{Na}^{+}+\mathrm{K}^{+}+\mathrm{Ca}^{2+}+\mathrm{Mg}^{2+}\right]-\left[\mathrm{Cl}^{-}+1.8 \mathrm{P}\right](\mathrm{mEq})$ except for phosphate $(\mathrm{mmol})$. While, the amount of net acid excretion was obtained by measuring (titrable acid $+\left[\mathrm{NH}_{4}{ }^{+}\right]$$\left[\mathrm{HCO}_{3}^{-}\right]$), because secreted $\mathrm{H}^{+}$from renal tubules is subjected to two kinds of buffers, phosphate buffer and ammonia buffer. Data necessary for estimation of acid production were collected using HPLC. We used a Hitachi HPLC unit which consists of an intelligent pump L6200, a column oven L5025 and conductivity detector L7470 (Hitachi High-Technologies Corporation. Tokyo, Japan). The separation was performed on a Hitachi GLIC-C65 column with gourd column GL-IC-C75G for cation and 655-2618 for anion. An aliquot of the filtered and properly diluted urine was injected into an HPLC apparatus with $2.5 \mathrm{mmol} \mathrm{H}_{2} \mathrm{SO}_{4}$ solution as the mobile phase for cation and $2 \mathrm{mmol}$ p-hydroxy benzoic acid/1.5 mmol triethylamine for anion.

Titrable acid was estimated as the amount of $0.1 \mathrm{~mol}$ $\mathrm{NaOH}$ necessary to titrate back to $\mathrm{pH} 7.4$ from urine $\mathrm{pH}$. Bicarbonate concentration $\left(\left[\mathrm{HCO}_{3}{ }^{-}\right]\right)$was calculated using the Henderson-Hasselbach equation for which solubility coefficient of carbon dioxide was taken as $0.0309 \mathrm{mmol} / \mathrm{mmHg} \cdot \mathrm{L}$ and $\mathrm{P}_{\mathrm{Ka}}$ and $\mathrm{P}_{\mathrm{CO} 2}$ were assumed to be 6.10 and $40 \mathrm{mmHg}$, respectively. Urine $\mathrm{pH}$ was measured at $37^{\circ} \mathrm{C}$ with $\mathrm{pH}$ meter (D-58, Horiba, Kyoto, Japan). Organic acid salts were measured by the Van Slyke and Palmer method with the modification by Lennon, Leman and Litzow (1966)[5]. Briefly, urine was mixed with $\mathrm{Ca}(\mathrm{OH})_{2}$ and shaken for precipitating out phosphate. Portions of the filtrate were brought to $\mathrm{pH}$ 2.7 at $37^{\circ} \mathrm{C}$ with $1 \mathrm{~mol} \mathrm{HCl}$ with a $\mathrm{pH}$ meter. The solution then titrated with $0.1 \mathrm{~mol} \mathrm{NaOH}$ to original $\mathrm{pH}$ of the urine to estimate organic acid salts. The organic acid salt measured was corrected for titration of creatinine which was determined with the Folin method. Uric acid was measured by conventional uricase-peroxidase method, using an autoanalyzer.

\section{Statistical analysis}

A series of studies on the same principle has been conducted for three years consecutively. Each year 10, 7 and 9 participants were assigned to either an acid or alkali diet at the beginning of a 5-day study and then switched to the other kind of diet. The first and second diet periods were separated by one month. Because several participants were obliged to discontinue the project due to menstruation, two group populations were treated as independent samples instead of being treated as a paired set of data. Data were presented as mean \pm SD. The student $t$ test was used to test the significance of changes in measured parameters between the acid and 
alkali periods. Differences were assumed to be significant when $\mathrm{p}<0.05$.

\section{Results}

Change in urine $\mathrm{pH}$ and creatinine excretion

It took 3 days to reach a steady level of urine $\mathrm{pH}$ of 6.5 in the alkali diet and pH 5.9 in the acid diet after switching ordinal daily diets to each designed diet (Figure 1 and Table 1). During all experimental days, the total amount of creatinine excretion remained unchanged around 1000$1100 \mathrm{mg} / \mathrm{d}$, indicating that there is no significant fluctuation of GFR, because creatinine concentration in the serum of healthy young people seems to remain constant.

\section{Relationship between acid generation in the body and acid excretion in urine}

In order to confirm the achievement of proper loading of acid, we measured several factors relating with the endogenous fixed acid production and the urinary acid excretion and listed urinary ammonium, phosphate and sulfate together with urinary $\mathrm{pH}$ as a typical representative in Table 1. Significant difference in urine $\left[\mathrm{SO}_{4}{ }^{2-}\right]$ in the periods of the acid and alkali diets was associated with the amounts of sulfar-containing amino acid in foods of $4262 \mathrm{mg} / \mathrm{d}$ in the acid and $2061 \mathrm{mg} / \mathrm{d}$ in the alkali diets. Urinary ammonium, phosphate and sulfate were inversely related to the course of urinary $\mathrm{pH}$. On the intake of the alkali diet, these values were significantly lower than those in the acid diet (Table.1). Calculated total effective fixed acid production correlated closely with renal acid excretion, indicating that the metabolic degradation of food materials results in $\mathrm{H}^{+}$ appeared in urine (Figure 2).

Effect of change in urine $\mathrm{pH}$ on the uric acid excretion Data of excretion of uric acid in urine as expressed as uric acid excretion in $\mathrm{mg}$ per day $(\mathrm{mg} / \mathrm{d})$ were plotted

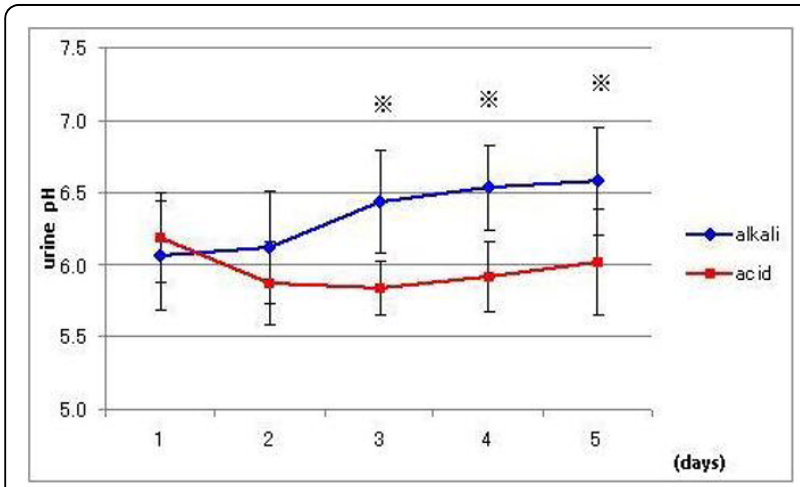

Figure 1 Effect of acid (square) and alkali (diamond) diets on urine $\mathrm{pH}$. Data are presented as mean $\pm \mathrm{SD}$. Asterisks indicate statistical significance between two groups $(p<0.002)$.
Table 1 Comparison of estimated urinary excretion of ions associated with the acid-base balance which were obtained by averaging data of last 3 experimental days in the acid diet with those in the alkali diet $(n=102)$

\begin{tabular}{cccc}
\hline & alkali diet & acid diet & $\mathbf{p}$ \\
\hline urine volume(L/d) & $1.50 \pm 0.63$ & $1.37 \pm 0.65$ & $\mathrm{NS}$ \\
$\mathrm{pH}$ & $6.51 \pm 0.34$ & $5.92 \pm 0.28$ & $<0.01$ \\
ammonium(mmol/d) & $24.11 \pm 12.78$ & $52.13 \pm 13.27$ & $<0.01$ \\
phosphate $(\mathrm{mmol} / \mathrm{d})$ & $24.64 \pm 10.37$ & $35.76 \pm 14.69$ & $<0.01$ \\
sulfate $(\mathrm{mmol} / \mathrm{d})$ & $9.94 \pm 3.25$ & $21.51 \pm 6.21$ & $<0.01$ \\
uric acid $(\mathrm{mg} / \mathrm{d})$ & $413.40 \pm 81.76$ & $302.84 \pm 134.78$ & $<0.01$
\end{tabular}

against urine $\mathrm{pH}$ (Figure 3). The amount of excreted uric acid increased with increase in luminal $\mathrm{pH}$. Applying a linear line obtained by the least square method, the amount of uric acid excreted was calculated to be $308 \mathrm{mg} / \mathrm{d}$ at $\mathrm{pH} 5.9$ and $407 \mathrm{mg} / \mathrm{d}$ at $\mathrm{pH} 6.5$ where specified $\mathrm{pH}$ values are corresponding to those steady state values for acid and alkali loading periods. These calculated values are very close to those observed shown in Table 1.

\section{Discussion}

The results obtained in this study are as follows; as urine $\mathrm{pH}$ is increased by suppression in the generation of $\mathrm{H}^{+}$through metabolic degradation of food materials, uric acid excretion increases significantly. The significance of this finding is that although the purine content was less in the alkaline diet compared to the acid diet, the transportable proportion of uric acid (in conjugate base) $\left(\mathrm{P}_{\mathrm{Ka}}=5.35\right)$ was larger in alkaline urine compared with acid urine. These data demonstrate that excretion of uric acid is suppressed in acidic medium. Although

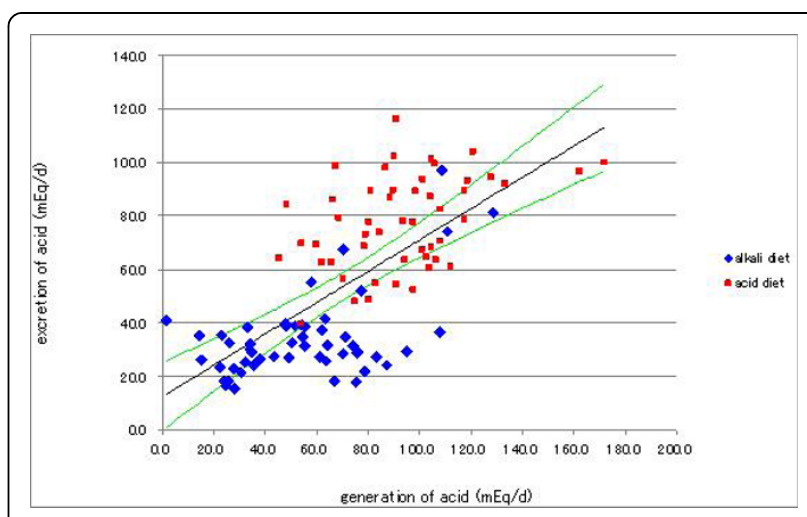

Figure 2 Relationship between endogenous acid generation and renal acid excretion. Diamonds indicate data for the alkali diet and squares those for the acid diet. The equation for the straight line adopted to data by the least square method is $y=$ $0.834 \times+27.09\left(R^{2}=0.362, n=102, p<0.01\right)$. The lines above and below the regression line are the $99 \%$ confidence limits. 


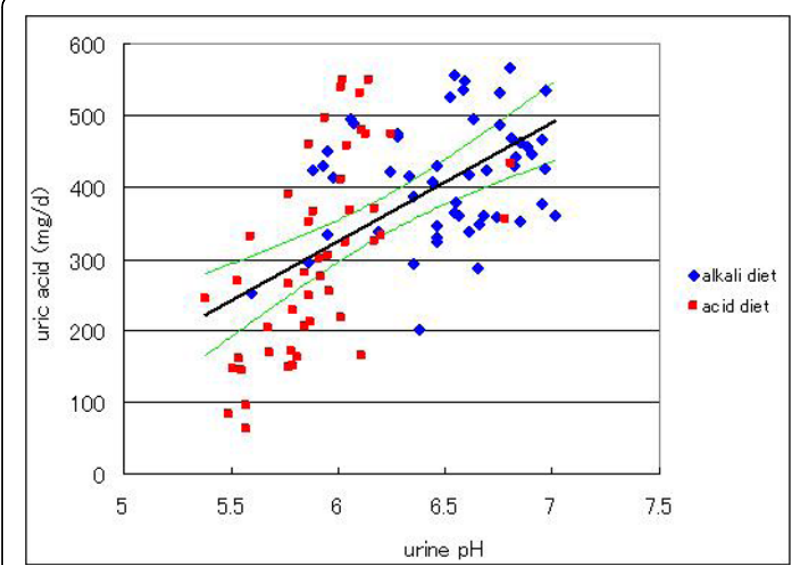

Figure 3 Relationship between excreted uric acid as expressed in $\mathrm{mg}$ uric acid in urine per day and urine $\mathrm{pH}$. Diamonds indicate data for the alkali diet and squares those for the acid diet. Equation for the straight line obtained by the least square method is $y=165 x-669\left(R^{2}=0.342, n=102, p<0.01\right)$. The lines above and below the regression line are the $99 \%$ confidence limits.

Griebsch and Z囚llner (1974)[7] and Clifford, Riumallo, Young and Scrimshaw (1976)[8] have reported that oral purines increase uric acid concentration in serum as well as in urine in dose-dependent manner, we unexpectedly observed the elevation of uric acid excretion in alkali urine while subjects took low-purine diets. This finding strongly suggests that $\mathrm{pH}$-dependent uric acid transport system in human kidney might be intimately committed in excretion of uric acid. Our study provides a key to explain a long standing view that gout is most common among people whose diet is rich in meat and low in vegetable and fruits. Because sulfur-containing amino acids, a main determinant of urine acidity, are contained abundant in animal proteins, people who take diets rich in animal protein will excrete more acidic urine than those having diets low in animal proteins and rich in vegetable and fruits, leading to the difficulty in uric acid removal. Thus, animal protein eaters are more susceptible to gout than vegetable eaters.

Since urine $\mathrm{pH}$ could be changed at will by selecting food materials suitable for desired urine $\mathrm{pH}$, one can take preventive procedures for gout without side effects by following appropriate diets.

Because prehistoric Homo sapiens seem to excrete alkaline urine by eating a large amount of high-bicarbonate-yielding plant foods, they would have excreted uric acid more easily than contemporary human being. However, the transition of preagricultural diet to the modern diet with the displacement of plant foods in the pre-historic diet with energy-dense, nutrient-poor foods without buffering capability, such as separated fats, refined sugars and vegetable oil in the contemporary diet, results in a net acid load [9] and makes uric acid excretion difficult. In fact, the Yanomamo Indians eating the vegetable-based diets are reported to have serum uric acid levels in as low as $3 \mathrm{mg} / \mathrm{dl}$ even in male which is slightly higher than uric acid observed in primates that express uricase [10]. Although both sulfuric acid and organic acid production rates are lower in the contemporary diet than in the preagricultural diet [9], bicarbonate production is disproportionately lower, thereby shifting urine $\mathrm{pH}$ to acid and facing the difficulty of uric acid removal for modern human beings.

\section{Conclusion}

This study has clarified that alkalization of urine by the manipulation of food materials promotes the removal of uric acid. When one pays enough attention to the construction of a nutritionally balanced menu, dietary intervention becomes the safest and the most economical way for the prevention of hyperuricemia.

\section{Appendix}

The composition of the acid and alkali diets is listed below as consumed amounts, g/day. Energy and protein contents in the acid and alkali diets were $2222 \mathrm{kcal} / \mathrm{d}$ and $2212 \mathrm{kcal} / \mathrm{d}$, and $102 \mathrm{~g} / \mathrm{d}$ and $60 \mathrm{~g} / \mathrm{d}$, respectively.

\section{(Alkali diet)}

white rice $100 \mathrm{~g}$, rye bread $70 \mathrm{~g}$, pasta $80 \mathrm{~g}$, starch 20 $\mathrm{g}$, hard tofu $100 \mathrm{~g}$, pressed tofu $30 \mathrm{~g}$, fried tofu $6 \mathrm{~g}$, okara 40 g, green soybeans 10 g, milk 150 g, carrot 20 g, leaf vegetable $65 \mathrm{~g}$, tomato $120 \mathrm{~g}$, pepper (red \& yellow) $30 \mathrm{~g}$, pumpkin $80 \mathrm{~g}$, green onion $15 \mathrm{~g}$, onion $50 \mathrm{~g}$, cucumber $60 \mathrm{~g}$, cabbage $60 \mathrm{~g}$, lettuce $30 \mathrm{~g}$, garlic $5 \mathrm{~g}$, potato $100 \mathrm{~g}$, aroid $45 \mathrm{~g}$, yam $30 \mathrm{~g}$, mushroom $40 \mathrm{~g}$, banana $45 \mathrm{~g}$, water melon $90 \mathrm{~g}$, walnuts $15 \mathrm{~g}$, dried seaweed $3 \mathrm{~g}$, sugar $4 \mathrm{~g}$, honey $21 \mathrm{~g}$, olive oil $6 \mathrm{~g}$, salad oil $12 \mathrm{~g}$, dressing $10 \mathrm{~g}$, butter $12 \mathrm{~g}$, soy source $9 \mathrm{~g}$, vinegar $3 \mathrm{~g}$, soup prepared from dried bonito and tangle $180 \mathrm{~g}$, alcohol for cooking $15 \mathrm{~g}$, miso (fermented soybeans paste) $9 \mathrm{~g}$, sauce $25 \mathrm{~g}$, chili pepper $1 \mathrm{~g}$, sweet cooking rice wine $4 \mathrm{~g}$, salt $1.3 \mathrm{~g}$, pepper $0.09 \mathrm{~g}$, mayonnaise $12 \mathrm{~g}$.

\section{(Acid diet)}

white rice $200 \mathrm{~g}$, bread 90 g, boiled pasta 45 g, starch $6 \mathrm{~g}$, beef round $100 \mathrm{~g}$, cero $90 \mathrm{~g}$, chicken breast fillet 30 g, squid $30 \mathrm{~g}$, egg $100 \mathrm{~g}$, processed cheese $20 \mathrm{~g}$, carrot $50 \mathrm{~g}$, broccoli $20 \mathrm{~g}$, snap pea $20 \mathrm{~g}$, asparagus $20 \mathrm{~g}$, green onion $10 \mathrm{~g}$, bamboo sprout $65 \mathrm{~g}$, corn $25 \mathrm{~g}$, onion $50 \mathrm{~g}$, burdock $15 \mathrm{~g}$, sprout $20 \mathrm{~g}$, tomato source $15 \mathrm{~g}$, soy source $6 \mathrm{~g}$, salt $0.8 \mathrm{~g}$, sweet cooking rice wine $12 \mathrm{~g}$, alcohol for cooking $20 \mathrm{~g}$, pepper $0.09 \mathrm{~g}$, miso $9 \mathrm{~g}$, consommé $1 \mathrm{~g}$, soup prepared from dried bonito and tangle $150 \mathrm{~g}$, mayonnaise $12 \mathrm{~g}$, butter $4 \mathrm{~g}$, salad oil $8 \mathrm{~g}$, sugar 9 g, strawberry jam 20 g. 


\section{Acknowledgements}

Third author acknowledges that this work was supported in part by

Hiroshima Jyogakuin University research grant.

\section{Author details}

'Department of Nutrition and Health Promotion, Faculty for Human Development, Hiroshima Jyogakuin University. 4-13-1 Ushita-higashi Higashiku Hiroshima 732-0063 Japan. ${ }^{2}$ Department of Nutritional Sciences, Faculty of Human Ecology, Yasuda Women's University. 6-13-1 Yasuhigashi, Asaminami-ku, Hiroshima 731-0153 Japan.

\section{Authors' contributions}

AK carried out the analysis of all urine contents and the integration of data into the report. $\mathrm{MH}$ participated in the design of the study and helped to draft the manuscript. IS conceived of the study, helped to draft the manuscript and participated in analysis and integration of data.

All authors have read and approved the final manuscript.

\section{Competing interests}

The authors declare that they have no competing interests.

Received: 13 May 2010 Accepted: 19 October 2010

Published: 19 October 2010

\section{References}

1. Feig DI, Kang D, Johnson RJ: Uric Acid and Cardiovascular Risk. N Engl J Med 2008, 359:1811-21

2. Hagos Y, Stein D, Ugele B, Burckhardt G, Bahn A: Human Renal Organic Anion Transporter 4 Operates as an Asymmetric Urate Transporter. J Am Soc Nephrol 2007, 18:430-9.

3. Guggino SE, Martin GJ, Aronson PS: Specificity and modes of the anion exchanger in dog renal microvillus membranes. Am J Physiol Renal Physio 1983, 244:612-21.

4. Kahn $\mathrm{M}$, Weinman EJ: Urate transport in the proximal tubule: in vivo and vesicle studies. Am J Physiol Renal Physiol 1985, 249:789-98.

5. Lennon EJ, Lemann J Jr, Litzow JR: The effects of diet and stool composition on the net external acid balance of normal subjects. J Clin Invest 1966, 45:1601-7.

6. Oh MS: A new method for estimating G-I absorption of alkali. Kidney Int 1989, 36:915-17.

7. Griesch $A, Z \mathbb{Z} \|$ ner N: Effect of ribomononucleotides given orally on uric acid production in man. Adv Exp Med Biol 1974, 41B:443-49.

8. Clifford AJ, Riumallo JA, Young VR, Scrimshaw NS: Effect of oral purines on serum and urinary uric acid of normal, hyperuricemic and gouty humans. J Nutr 1976, 106:428-434.

9. Sebastian A, Frassetto LA, Sellmeyer DE, Merriam RL, Morris RC Jr: Estimation of the net acid load of the diet of ancestral preagricultural Homo sapiens and their hominid ancestors. Amer J Clin Nutr 2002, 76:1308-16.

10. Johnson RJ, Sautin YY, Oliver WJ, Roncal C, Mu W, Sanchez-Lozada LG, Rodriguez-Iturbe B, Nakagawa T, Benner SA: Lessons from comparative physiology: could uric acid represent a physiologic alarm signal gone awry in western society? J Comp Physiol B 2009, 179:67-76.

doi:10.1186/1475-2891-9-45

Cite this article as: Kanbara et al:: Urine alkalization facilitates uric acid excretion. Nutrition Journal 2010 9:45.

\section{Submit your next manuscript to BioMed Central and take full advantage of:}

- Convenient online submission

- Thorough peer review

- No space constraints or color figure charges

- Immediate publication on acceptance

- Inclusion in PubMed, CAS, Scopus and Google Scholar

- Research which is freely available for redistribution

Submit your manuscript at www.biomedcentral.com/submit
Biomed Central 